\title{
ASURANSI SOSIAL SYARIAH BAGI MUSLIM INDONESIA
}

\author{
Fatkhul Muin \& Rully Syahrul Mucharom \\ Fakultas Hukum Universitas Sultan Ageng Tirtayasa Serang-Banten \\ Jalan Raya Jakarta KM 4 Pakupatan Kota Serang \\ E-mail: fatkhulmoen@gmail.com \& rully_sm@yahoo.co.id
}

\begin{abstract}
Syariab Social Insurance for Muslims Indonesia. The basic concept of the insurance is because people need protection against any incident that occurs in the community such as illness and natural disasters. The article 14 In Law No. 2 of 1992 on Insurance, that social insurance is a type of insurance to the implemented by the government for public welfare. The current population is Moslem Indonesia reached 80\%, therefore, the Indonesian Muslim community needs the systema syariah social insurance. The system of syariah social insurance where there are 2 (two) products, where there are participants and savings accounts tabarru' and as managers by the BUMN (state corporation) in law No. 2 of 1992 on Insurance.
\end{abstract}

Keyword: social insurance, moslem, society, goverment

\begin{abstract}
Abstrak: Asuransi Sosial Syariah bagi Muslim Indonesia. Konsep dasar terhadap asuransi adalah karena masyarakat membutuhkan perlindungan terhadap setiap kejadian yang terjadi dalam masyarakat seperti sakit dan bencana alam. Pasal 14 UU No. 2 tahun 1992 tentang Perasuransian menyebutkan bahwa asuransi sosial merupakan jenis asuransi yang dijalankan pemerintah untuk kesejahteraan masyarakat. Saat ini penduduk Indonesia yang beragama islam mencapai $80 \%$, oleh karena itu, masyarakat Muslim Indonesia membutuhkan sistem asuransi sosial syariah. Sistem oprasional asuransi sosial syariah pada hakikatnya sama sengan sistem yang digunakan olah asuransi syariah, dimana ada 2 (dua) produk, yaitu tabungan peserta dan rekening tabarru'. Sebagai pengelolanya adalah BUMN sesuai dengan ketentuan UU No. 2 Tahun 1992 Tentang Perasuransian.
\end{abstract}

Kata Kunci : asuransi sosial, muslim, masyarakat, pemerintah

\section{Pendahuluan}

Asuransi sebagai usaha yang melibatkan dua pihak dimana para pihak hakikatnya adalah untuk memberikan jaminan kepada pihak lain sebagai akibat adanya kerugian yang mungkin terjadi oleh satu pihak sebagi akibat dari adanya pristiwa. Pihak yang ditanggung harus membayar premi kepada pihak yang tertanggung berdasarkan perjanjian yang dibuat oleh pihak yang penanggung. ${ }^{1}$ Eksistensi asuransi dengan memberikan perlindungan kepada pihak tertanggung dalam jangka waktu tertentu oleh pennanggung sesuai dengan perjanjian yang dibuat oleh para pihak. Dalam perkembangan perusahaan

\footnotetext{
Naskah diterima: 22 Oktober 2014, direvisi: 3 November 2015, disetujui untuk terbit: 22 Desember 2014.

1 Merujuk pada pasal 246 KUHD yang dikutip oleh Djoko Prakoso bahwa dalam asuransi itu dapat disimpulkan ada usur antara lain: (1) Pihak tertanggung, dalam bahasa Belanda disebut dengan "verzekering" yang mempunyai kewajiban membayar uang premi kepada pihak penanggung, sekaligus atau berangsung-angsur. (2) Pihak penanggung mempunyai kewajiban untuk membayar sejumlah uang kepada pihak tertanggung, sekaligus atau berangsung-angsur apabila maksud unsur ketiga berhasil. (3) Suatu kejadian yang semula belum jelas akan terjadi.
}

perasuransian kemudian lahir asuransi sosial yang diselenggarakan oleh negara. Asuransi sosial merupakan model pemberian kesejahteraan bagi masyarakat dalam bentuk memberikan perlindungan yang berbasis kepada perlindungan yang didasarkan kepada iuran yang dilaksanakan secara kolektif untuk membantu masyarakat secara keseluruhan. Asuransi secara etimologi merupakan pertanggungan yaitu perjanjian antara dua pihak, pihak yang satu berkewajiban membayar iuran dan pihak yg lain berkewajiban memberikan jaminan sepenuhnya kepada pembayar iuran apabila terjadi sesuatu yg menimpa pihak pertama atau barang miliknya sesuai dengan perjanjian yg dibuat. ${ }^{2}$ Perjanjian asurnasi pada dasarnya mempunyai tujuan untuk mengganti kerugian pada pertanggungan, jadi tertanggung harus dapat menunjukan bahwa dia menderita kerugian dan benar-benar menderita kerugian. ${ }^{3}$

Selain asuransi yang dijalankan oleh pihak swasta,

\footnotetext{
2 Kementerian Pendidikan Nasional, Kamus Besar Bahasa Indonesia, dalam http://bahasa.kemdiknas.go.id/kbbi/index.php. diakses pada 15 Maret 2014.

${ }^{3}$ Djoko Prakoso, Hukum Asuransi Indonesia, ( Jakarta: Rineka Cipta, 2004), h. 9.
} 
pemerintah melalui BUMN berkewajiban untuk menjalankan asuransi sosial dalam rangka melindungi masyarakat. Asuransi sosial menurut The Committe on Social Insurance Terminology of The Amirican Risk and Insurance Association adalah:

A device for the poling of the risk by their transfer to an organization, usually governmental, that is required by law to provide pecuniary or service benefits to or on behalf of covered persons upon the occurences of certain predesignated losses under all of the following conditions: (1) Coverage is compulsory by law in virtually all instances. (2) Except during a transition period following its intrudaction, eligibility for benefits is derived, in fact or effect, from contributions having been made to the program by or in respect of the claimant is a dependent. There is on requirement that the individual demonstrate inadequate financial resources, although a depedency status my need to be estabilished. (3) The method for determining the benefiits is prescribed by law. (4) The benefits for any individual are not usually directly related to contributions made by or in respect of him but instead usually redistribute income so as to favor groups such as those with low former wages or a large number of dipendents. (5) There is a definite plan for financing the benefits that is desigened to be adequate in the trems of long-range considration. (6) The cost is borne primarily by contributions which are usually made by coverd persons, their employers or both. (7) The plan is administered or at least supervised by the government. (8) The plan is not esthablished by the government solely for its present or former employees. ${ }^{4}$

Menurut Emmy Pangaribuan Simanjuntak bahwa asuransi sosial mempunyai ciri-ciri sebagai berikut: (1) Yang menyelenggarakan pertanggungan biasanya itu adalah pemerintah. Dengan perkataan lain penanggungnya adalah pemerintah. (2) Sifatnya hubungan hukum pertanggungan itu adalah wajib bagi seluruh anggota masyarakat atau sebagian anggota masyarakat. (3) Penentuan penggantian kerugian diatur oleh pemerintah dengan peraturan. (4) Tujuannnya adalah untuk memberikan suatu jaminan sosial (social security), bukan untuk mencari keuntungan. Melaksanakan apa yang menjadi tujuannya. Ini adalah merupakan kewajiban bagi pemerintah. ${ }^{5}$

Berdasarkan data Biro Pusat Statistik, bahwa jumlah penduduk Indonesia telah mencapai 237.641.326. ${ }^{6}$ Jumlah penduduk yang besar tersebut tentu mem-

\footnotetext{
${ }^{4}$ Kun Wahyu Wardana, Hukum Asuransi Proteksi Kecelakaan Trnsportasi, (Bandung: Mandar Maju, 2009), h. 45.

${ }^{5}$ Man Suparman Sastrawidjaja, dkk, Hukum Asuransi Perlindungan Tertanggung Asuransi Deposito Usaha Perasuransian, (Bandung: Penerbit PT Alumni 2004), h. 68.

${ }^{6} \mathrm{Jumlah}$ penduduk Indonesia berdasarkan BPS tersebut menunjukkan bahwa umat Islam di Indonesia mencapai 88\% dari keseluruhan jumlah penduduk di Indonesia. Hal tersebut menunjukkan bahwa keberadaan asuransi sosial diperlukan bagi umat Islam, sebagai bagian dari amanat konstitusi bahwa umat Islam di Indonesia diberikan kebebasaan untuk menjalankan agamanya.
}

butuhkan perlindungan terhadap setiap warga negara sesuai dengan amanat konstitusi/UUD NRI 1945. Asuransi sosial sebagai bagian dari perlindungan terhadap warga negara, maka dapat juga dipergunakan untuk perlindungan asuransi sosial bagi seluruh rakyat Indonesia, karena asuransi sosial tidak beroreantasi pada keuntungan bahkan penanggung asuransi adalah negara melalui pemerintah bersama-sama dengan masyarakat.

Eksistensi asuransi sosial yang saat ini ada tentu tidak hanya pada kontek asuransi sosial yang berorentasi pada asuransi konvensional, tetapi asuransi sosial yang berbasis pada asuransi syariah perlu menjadi perhatian terhadap pemerintah, karena mayoritas penduduk Indonesia beragama Islam. Asuransi sosial berbasis syariah sebagai upaya pemenuhan kebutuhan umat Islam Indonesia dalam menjalankan syariat dengan berlandaskan kepada Alquran, Sunah, Ijmak dan Qiyas sebagai basis dasar dalam menjalankan syariat.

\section{Asuransi Sosial di Indonesia}

Program asuransi sosial sebagai program asuransi yang diselenggarakan secara wajib berdasarkan undang-undang dengan tujuan untuk memberikan perlindungan dasar bagi kesejahteraan masyarakat.? Program asuransi sosial hanya dapat dilaksanakan oleh Badan Usaha Milik Negara. Terhadap perusahaan yang menyelenggarakan program asuransi soasial berlaku pembinaan dan pengawasan sesuai dengan ketentuan undang-undang. ${ }^{8}$

Dalam ketentuan Pasal 1 ayat (1) Undang-Undang No. 2 Tahun 1992 tentang Usaha Perasuransian disebutkan bahwa:

Asuransi atau pertanggungan adalah perjanjian antara dua pihak atau lebih, dengan mana pihak penanggung mengikatkan diri kepada tertanggung, dengan menerima premi asuransi, untuk memberikan penggantian kepada tertanggung karena kerugian, kerusakan atau kehilangan keuntungan yang diharapkan atau tanggung jawab hukum kepada pihak ketiga yang mungkin akan diderita tertanggung, yang timbul dari suatu peristiwa yang tidak pasti, atau untuk memberikan suatu pembayaran yang didasarkan atas meninggal atau hidupnya seseorang yang dipertanggungkan. Tujuan dari pertanggungan sosial (social insurance) adalah untuk menyediakan suatu bentuk jaminan tertentu kepada seseorang atau anggota masyarakat yang menderita kerugian dalam memperjuangkan hidupnya dan keluarganya.

${ }^{7}$ Lihat UU No. 2 Tahun 1992 tentang Usaha Perasuransian Pasal 1 angka 3 .

${ }^{8}$ Lihat UU No. 2 Tahun 1992 tentang usaha Perasuransian Pasal 14 ayat 1 dan 2.

9 Emmy Pangaribuah Simajuntak, Hukum Pertanggungan dan Perkembangannya, (Yogyakarta: Seksi Hukum Dagang Fakultas Hukum UGM, 1980), h. 106. 
Asuransi sosial berkembang sebagai bentuk lanjutan dari asuransi komersial. Hal ini disebabkan, asuransi sosial diselenggarakan sebagai usaha untuk memberikan jaminan sosial kepada masyarakat. Semula jaminanan sosial merupakan program yang bersifat sosial (welfare program), yaitu memberikan bantuan baik yang bersifat financial, medical maupun pelayanan lainnya bagi mereka yang tidak mampu. ${ }^{10}$

Menurut George E Redja, ada 3 alasan yang membuat program asuransi sosial pensting untuk dilaksanakan, yaitu: (1) Program asuransi sosial diberlakukan untuk mengatasi permasalahan sosial yang kompleks. Masalah sosial bukanlah soal sepele. Sebagian atau bahkan seluruh masyarakat bisa terkena dampaknya. Sehingga keterlibatan langsung pemerintah dibutuhkan untuk mengatasinya. (2) Program asuransi sosial juga dibutuhkan karena terdapat perlis tertentu yang secara komersial sulit diasuransikan. (3) Program asuransi sosial dibutuhkan untuk memberikan jaminan secara ekonomi kepada masyarakat. ${ }^{11}$

Secara umum ada beberapa prinsip dasar dalam menjalankan asuransi sosial yang dilaksanakan oleh pemerintah, antara lain: (1) Compulsion (Wajib), (2) Set Level of Benefit (Manfaat yang merata/sama), (2) Floor of Protection (Perlindungan mendasar), (3) Subsidy (Subsidi), (4) Unpredictability of Loss (Kerugian sulit diprediksi), (5) Conditional Benefits (Manfaat bersyarat), (6) Contribution Required (Harus ada kontribusi), (7) Attachment to Labor Force (Terkait dengan Tenaga Kerja) dan (8) Minimal Advance Funding (Minimum dalam penyisihan dana). ${ }^{12}$

Program asuransi sosial yang diselenggarakan oleh pemerintah bersama dengan masyarakat akan memberikan dampak yang positif terhadap masyarakat terutama berkaitan dengan kelaikan kehidupan masyarakat secara umum untuk menciptakan amanat pembukaan UUD NRI 1945, dimana negara memiliki kewajiban untuk menciptakan kesejahteraan kepada masyarakat Indonesia. Amanat konstitusi tersebut kemudian dituangkan dalam ketentuan UU No. 2 Tahun 1992 tentang Perasuransian, dimana dalam ketentuan pasal 14 ayat (1) disebutkan bahwa asuransi sosial harus diselenggaraakan oleh pemerintah.

Indonesia memiliki asuransi sosial yang diselenggarakan oleh BUMN sesuai dengan amanat UU No. 2

\footnotetext{
${ }^{10}$ Sentanoe Kartonegoro, Jaminan Sosial Perencanaan, Pembiayaan dan Peranannya, (Jakarta: Mutiara Sumber Wijaya, 1989), h. 23.

${ }^{11}$ Kun Wahyu Wardana, Hukum Asuransi Proteksi Kecelakaan Trnsportasi, h. 44.

${ }^{12}$ Sentanoe Kartonegoro, Jaminan Sosial Perencanaan, Pembiayaan dan Peranannya, h. 48.
}

Tahun 1992 tentang Perasuransian, seperti Askep (Asuransi Sosial Kecelakaan Penumpang). Askep diatur dalam ketentuan Undang-Undang No. 33 Tahun 1964 tentang Dana Pertanggungan Wajib Kecelakaan Penumpang. Selain itu ada Askes bagai PNS, Jamsostek bagi karyawan dan Asabri. Dalam perkembangannya, asuransi sosial yang diselenggarakan oleh negara melalui BUMN, dikelola secara terpadu oleh satu badan yaitu BPJS. UU BPJS membentuk BPJS dan mengubah kelembagaan PT ASKES (Persero) dan PT JAMSOSTEK (Persero). Transformasi kelembagaan diikuti adanya pengalihan peserta, program, aset dan liabilitas, serta hak dan kewajiban. UU Nomor 24 Tahun 2011 tentang BPJS membentuk dua Badan Penyelenggara Jaminan Sosial, yaitu BPJS Kesehatan dan BPJS Ketenagakerjaan BPJS Kesehatan menyelenggarakan program jaminan kesehatan bagi seluruh penduduk Indonesia termasuk pekerja asing yang bekerja di Indonesia sekurang-kurangnya enam bulan. ${ }^{13}$ BPJS Ketenagakerjaan menyelenggarakan program jaminan kecelakaan kerja, jaminan hari tua, jaminan pensiun dan jaminan kematian bagi seluruh tenaga kerja di Indonesia. ${ }^{14}$

Keberadaan BPJS sebagai asuransi sosial tentu dapat memberikan jaminan sosial bagi masyarakat Indonesia dengan partisipasi masyarakat dan pemerintah dalam rangka memperkuat jaminan sosial bagi masyarakat.

\section{Hakikat Akad Muamalat}

Permasalahan yang terjadi di masyarakat dunia dalam bidang muamalat pada umumnya merupakan impelentasi mumalat sesuai dengan nilai-nilai syariat yang telah ditentukan dalam ketentuan Alquran, Sunah, Ijmak dan qiyas. Riba dan maysîr (judi) menjadi indikator dalam muamalat untuk menentukan bahwa akad sesuai dengan ketentuan dalam syariat. Asal makna riba menurut bahasa arab ialah lebih (bertambah).

Adapun yang dimaksud disini menurut istilah syariat adalah akad yang terjadi dengan penukaran tertentu, tidak diketahui sama atau tidaknya menurut aturan syariat atau terlambat menerimanya. ${ }^{15}$ Riba pada umumnya terjadi dalam muamalat dengan konsep hutang piutang yang menjadikan dasarnya adalah hutang pokok dengan ditambah kelebihan kepada yang memberikan hutang kepada si piutang. Ini yang

\footnotetext{
${ }^{13}$ Lihat Pasal 6 Ayat (1) UU No. 24 Tahun 2011 tentang BPJS.

${ }^{14}$ Lihat Pasal 6 Ayat (2) UU No. 24 Tahun 2011 tentang BPJS.

15 Riba terbagi menjadi macam, yaitu riba fadhli, riba qardhi, riba yad dan riba nasấ. Walaupun seperti pembagian di atas, menurut sebagian ulama mengatakan bahwa riba terbagai tiga saja, yaitu riba fadhli, riba yad dan riba nasâ. Sulaiman Rasjid, Fiqih Islam, (Bandung : Sinar Baru Algensindo, 2006), h.290.
} 
menjadikan lahirnya riba dalam masyarakat umat Islam. Larangan riba diturunkan tidak sekaligus melainkan diturunkan dalam 4 tahap, dimana pada tahapan-tahapan tersebut diturunkannya ayat-ayat Alquran untuk larangan riba. Adapun tahapan-tahapan tersebut antara lain: (1) Penolakan terhadap makna riba sebagai upaya untuk saling menolong sesama manusia sebagaimana disebutkan dalam Q.s. al-Rûm [30]: 39. (2) Riba diilustrasikan sebagai perbuatan yang buruk dan Allah Swt akan memberikan balasan yang setimpal kepada orang Yahudi yang memakan barang riba sebagaimana disebutkan dalam Q.s. al-Nisâ [4]: 160-161. (3) Perbuatan riba diharamkan karena menimbulkan kerugian terhadap sesama manusia sebagai akibat dari perbuatan melipatgandakan atas suatu utang sebagaimana disebutkan dalam Q.s. Âli 'Imrân [3]: 130. (4) Allah Swt dengan jelas dan tegas mengharamkan apapun jenis tambahan yang diambil dari pinjaman sebagaimana disebutkan dalam Q.s. alBaqarah [2]: 278-279. Ini adalah ayat yang terakhir yang diturunkan menyangkut riba.

Sedangkan maysîr (judi) merupakan salah satu amalan muamalat yang saat ini dilaksanakan oleh masyarakat dengan cara menginvestasikan uang melalui program asuransi yang tidak berbasisi oprasionalnya dengan oprasional syariah, sehingga melahirkan ketidakpastian terhadap yang investasi uang dalam program asuransi tersebut dan dapat melahirkan muamalat yang bersumber pada maysîr (judi).

Sedangkan gharar merupakan suatu hal yang tidak dapat diukur atau tidak jelas, sehingga ketidakjelasan tersebut tidak memberikan nilai apa-apa terhadap akad yang terjadi. Akad yang dilaksanakan pada hakikatnya merupakan akad tabaddulî atau akad pertukaran. Dalam akad pertukaran, barangnya harus jelas dan terlihat sehingga tidak menimbulkan keragu-raguan dalam akad tersebut dan jelas akadnya.

Riba, maysîr (judi) dan gharar (ketidakjelasan) tidak menutup kemungkinan dilaksanakan dalam akad asuransi yang tidak melandasi akadnya dengan syariat. Oleh karena itu ketentuan-ketentuan yang termaktub dalam Alquran dan Sunah menjadi batasan untuk menghindari hal-hal tersebut.

\section{Jaminan Sosial dan Peran Negara}

Pemahaman terhadap makna jaminan sosial merupakan hakikat kewajiban yang bersifat substansial, dimana peran negara yang besar dalam rangka menciptakan kesejahteraan kepada masyarakat yang bersifat berkelanjutan. Menurut A.M. Saefudin, yang dikutip oleh Mohammad Daud Ali, bahwa peran negara pada umumnya, pemerintah pada khusunya, sangat menentukan dalam pelaksanaan nilai-nilai sistem ekonomi Islam. Peranan itu diperlukan dalam aspek hukum, perencanaan dan pengawasan alokasi atau distribusi sumber daya dan dana, pemerataan pendapatan dan kekayaan serta pertumbuhan dan stabilitas ekonomi. ${ }^{16}$ Besarnya peran negara dalam memberikan kesejahteraan masyarakat salah satunya dengan menciptakan sistem asuransi sosial bagi masyarakat.

Dalam pelaksanaan asuransi sosial yang diatur dalam pasal 14 ayat (1) UU No. 2 tahun 1992 tentang usaha perasuransin, dimana saat ini pemerintah hanya menjalankan usaha asuransi yang bersifat konvensional dimana akad yang dibangun tidak didasarkan pada akad tabarru', tetapi semata hanya mengedepankan akad yang bersifat tabaddulî (pertukaran) sehingga mengakibatkan ketidakjelasaan akad dalam asuransi tersebut.

Menurut Syafie Antonio, sebagaimana dikutip oleh Abdulkadir Muhammad, bahwa ketidakjelasan terjadi dalam 2 (dua) bentuk, yaitu: pertama, akad syariah yang melandasai penutupan polis. Kontrak dalam asuransi jiwa konvensional dikategorikan sebagai akad pertukaran (tabaddulî), yaitu pertukaran pembayaran premi dengan uang pertanggungan. Secara harfiah dalam akad pertukaran harus jelas berapa yang dibayarkan dan berapa yang diterima. Keadaan ini menjadi tidakjelas (gharar) karena tidak tahu berapa yang akan diterima (sejumlah uang pertanggungan) dan tidak tahu berapa yang akan dibayarkan (sejumlah seluruh premi) karena hanya Allah yang tahu kapan seseorang akan meninggal. Dalam konsep takâful (saling menolong), keadaan ini akan lain karena akad yang digunakan adalah akad tolong menolong (takâfulî) dan saling menjamin dimana semua peserta asuransi menjadi penolong dan penjamin satu sama lainnya.

Kedua, sumber dana pembayaran klaim. Sumber dana pembayaran klaim dan keabsahan penerima uang klaim itu sendiri. Dalam konsep asuransi konvensional, tertanggung tidak mengetahui darimana dana pertanggungan yang diberikan oleh perusahaan asuransi berasal. Tertanggung hanya mengetahui jumlah pembayaran klaim yang akan diterima. Dalam konsep asuransi takâful (saling tolong menolong), setiap pembayaran premi sejak awal akan dibagi dua, rekening pemegang polis dan rekening peserta yang harus diniatkan sebagai dana kebajikan/derma (tabarru) untuk membantu saudaranya yang lain. Jadi, klaim dalam konsep asuransi takâful diambil dari dana

\footnotetext{
${ }^{16}$ Mohammad Daud Ali, Sistem Ekonomi Islam Zakat dan Wakaf, (Jakarta: UI Press, 1988), h. 16.
} 
tabarru' yang merupakan kumpulan dari dana sedekah yang diberikan oleh peserta asuransi. ${ }^{17}$

Asuransi sosial yang selama ini ada di Indonesia dan dikelola oleh BUMN pada dasarnya dapat menawarkan pola asuransi syariah berbasis takâfulî (tolong menolong) dengan dasar bahwa setiap orang memiliki polis dengan dasar sedekah untuk saling menolong masyarakat.

Pada asuransi sosial yang diselenggarakan oleh BUMN sesuai dengan ketentuan UU No. 2 Tahun 1992 tentang Perasuransian, pada hakikatnya dapat menggunakan pola asuransi sosial syariah oleh BUMN sebagai upaya untuk memberikan hak konstitusional umat Islam di Indonesia. Konsep asuransi sosial syariah yang dilaksanakan sama dengan asuransi sosial perusahaan dimana ada dua pihak yang berperan yaitu pemerintah sebagai bagian dari kewajiban untuk membantu masyarakat sebagai amanat konstitusi dan masyarakat yang menjadi asuransi sosial syariah. Asuransi sosial syariah yang berlandasakan pada saling tolong menolong masyarakat, dimana pemerintah memberikan dana kepada masyarakat sebagai dana jaminan sosial melalui APBN yang dikelola oleh perusahaan asuransi sosial syariah. Pengalokasian dana dari pemerintah tidak $100 \%$ (seratus persen) diberikan oleh pemerintah, tetapi ada premi asuransi yang harus dibayarkan oleh masyarakat. Dalam hal ini, dimana sistem pengoperasian asuransi sosial syariah merupakan tanggung jawab antara pemerintah dan masyarakat.

Dalam konsep asuransi sosial syariah, dimana tidak menggunakan prinsip mudhârabah (sistem bagi hasil), sebagaimana perusahaan asuransi syariah dimana para peserta takâful sebagai pemilik modal (shâhib al-mâl) dan perusahaan takâful sebagai pemegang amanah (mudhârib). ${ }^{18}$ Sistem operasional asuransi sosial syariah pada hakikatnya sama dengan sistem yang digunakan olah asuransi syariah, yaitu ada 2 produk, dimana ada tabungan peserta dan rekening tabarru'. Tabungan peserta merupakan milik peserta asuransi sosial syariah yang dikelola oleh BUMN dan akan dikembalikan kepada peserta sesuai dengan perjanjian yang dibuat oleh peserta dan masyarakat, sedangkan tabarru' merupakan konsep sedekah yang diberikan oleh peserta yaitu masyarakat dengan pola saling membantu antar masyarakat dan dikelola oleh pemerintah.

Dana tabarru' merupakan dana yang dimiliki oleh pemerintah dan masyarakat yang tergabung dalam asuransi sosial syariah, dimana dana tersebut sebagai

${ }^{17}$ Abdulqadir Muhammad, Hukum Asuransi Indonesia, (Bandung: PT. Citra Aditya Bakti, 2006), h. 264.

${ }^{18}$ Muhammad Syakir Sula, Asuransi Syariah (Life and General) Konsep dan Sistem Oprasional, (Jakarta: Gema Insani, 2004), h. 177. dana kebajikan untuk saling tolong menolong. Keanggotaan asuransi sosial diperuntukan bagi umat Islam di Indonesia, dimana melalui dana tabarru' tersebut dapat memberikan pertolongan kepada masyarakat Islam di Indonesia yang memang tidak mempunyai kemampuan secara ekonomi melalui asuransi sosial syariah.

Berdasarkan Keputusan Musyawarah Alim Ulama Nahdatul Ulama No. 03/Munas/1992 tentang Asuransi menurut Islam, bahwa salah satu butir keputusannya berkaitan dengan asuransi sosial yang berbasis syariah, dimana dalam ketentuan tersebut dinyatakan bahwa asuransi sosial tidak masuk dalam kategori mu'âwadah tetapi hanya masuk dalam kategori syirkah ta'âwuniyyah, sehingga konsep yang dibangun adalah konsep saling tolong menolong. Apabila terdapat keuntungan maka akan kembali kepada masyarakat dan apabila ada kerugian maka pihak pemerintah sesuai dengan ketentuan dalam UU No. 2 Tahun 1992 tentang Perasuransian, pemerintah yang meng-cover segala kerugian tersebut. ${ }^{19}$ Konsep asuransi sosial syariah yang dibangun berdasarkan syariat akan memberikan kesejahteraan bagi masyarakat.

\section{Penutup}

Asuransi secara etimologi merupakan pertanggungan, yaitu perjanjian antara dua pihak, pihak yg satu berkewajiban membayar iuran dan pihak yg lain berkewajiban memberikan jaminan sepenuhnya kepada pembayar iuran apabila terjadi sesuatu yg menimpa pihak pertama atau barang miliknya sesuai dengan perjanjian yg dibuat. Dalam perkembangannya, negara berkewajiban memberikan asuransi kepada masyarakat atau sering disebut dengan asuransi sosial (social insurance). Di Indonesia asuransi sosial diatur dalam Pasal 14 ayat (1 dan 2) UU No. 2 Tahun 1992 tentang Perasuransian, dimana asuransi sosial dilaksanakan oleh pemerintah melalui BUMN. Gagasan asuransi sosial syariah tentu menjadi penting mengingat umat Islam merupakan mayoritas penduduk Indonesia. Dalam konsep asuransi sosial syariah, dimana tidak menggunakan prinsip mudhârabah (sistem bagi hasil), sebagaimana perusahaan asuransi syariah dimana para peserta takâful sebagai pemilik modal (shâhib al-mâl) dan perusahaan takâful sebagai pemegang amanah (mudhârib). Sistem oprasional asuransi sosial syariah pada hakikatnya sama

${ }^{19}$ Selain keputusan NU yang membolehkan asuransi sosial demi kemaslahatan, Muktamar Muhammadiyah pun sebagaimana yang dikutip oleh Muhammad Syakir Sula, menyatakan bahwa asuransi diharamkan, tetapi asuransi sosial karena untuk kemaslahatan umat diperbolehkan. 
dengan sistem yang digunakan olah asuransi syariah, yaitu ada 2 produk, dimana ada tabungan peserta dan rekening tabarru'. Tabungan peserta merupakan milik peserta asuransi sosial syariah yang dikelola oleh BUMN dan akan dikembalikan kepada peserta sesuai dengan perjanjian yang dibuat oleh peserta dan masyarakat, sedangkan tabarru' merupakan konsep sedekah yang diberikan oleh peserta yaitu masyarakat dengan pola saling membantu antar masyarakat dan dikelola oleh pemerintah. []

\section{Pustaka Acuan}

Buku:

Ali, Mohammad Daud, Sistem Ekonomi Islam Zakat dan Wakaf, Jakarta: UI Press, 1988.

Kartonegoro, Sentanoe, Jaminan Sosial Perencanaan, Pembiayaan dan Peranannya, Jakarta: Mutiara Sumber Wijaya, 1989.

Muhammad, Abdulqadir, Hukum Asuransi Indonesia, Bandung: PT. Citra Aditya Bakti, 2006.

Prakoso, Djoko, Hukum Asuransi Indonesia, Jakarta: Rineka Cipta, 2004.
Rasjid, Sulaiman, Fiqih Islam, Bandung : Sinar Baru Algensindo, 2006.

Sastrawidjaja, Man Suparman, dkk, Hukum Asuransi Perlindungan Tertanggung Asuransi Deposito Usaha Perasuransian, Bandung: Penerbit PT Alumni 2004.

Simajuntak, Emmy Pangaribuah, Hukum Pertanggungan dan Perkembangannya, Yogyakarta: Seksi Hukum Dagang Fakultas Hukum UGM, 1980.

Sula, Muhammad Syakir, Asuransi Syariah (Life and General) Konsep dan Sistem Oprasional, Jakarta: Gema Insani, 2004.

Wardana, Kun Wahyu, Hukum Asuransi Proteksi Kecelakaan Trnsportasi, Bandung: Mandar Maju, 2009.

\section{Website:}

Kementerian Pendidikan Nasional, Kamus Besar Bahasa Indonesia, dalam http://bahasa.kemdiknas. go.id/kbbi/index.php, diakses pada 15 Maret 2014.

\section{Undang-Undang:}

Undang-Undang No. 2 Tahun 1992 tentang Usaha Perasuransian.

Undang-Undang No. 24 Tahun 2011 tentang BPJS. 